\title{
Possibility of Using Solar Energy for the Creation of Carbon Neutral Hotels in Mediterranean Countries
}

\author{
John Vourdoubas ${ }^{1}$ \\ ${ }^{1}$ Mediterranean Agronomic Institute of Chania, Chania Crete, Greece \\ Correspondence: Vourdoubas, John, Mediterranean Agronomic Institute of Chania, Chania Crete, Greece. Tel: 30- \\ 282-103-5020. E-mail: vourdoubas@maich.gr
}

Received: January 16, 2019

Accepted: February 6, 2019 Online Published: March 25, 2019

doi:10.5539/eer.v9n1p1

URL: https://doi.org/10.5539/eer.v9n1p1

\begin{abstract}
Mitigation of climate change requires the increased use of renewable energy sources instead of fossil fuels in all sectors. Hotel buildings utilize large amounts of energy consuming mainly electricity while the use of renewable energy sources is rather limited. Solar energy is abundant in the Mediterranean basin and it is currently used for heat and electricity generation in many applications. Various solar energy technologies are mature, reliable and cost-effective. Use of solar thermal energy, and solar photovoltaic energy combined with the use of high efficiency heat pumps, can cover all the energy needs for domestic hot water, space cooling and electricity in summeroperating hotels in the Mediterranean region. A summer-operating hotel located in Crete, Greece with a covered surface of $3000 \mathrm{~m}^{2}$ has a specific annual energy consumption of $150 \mathrm{KWh} / \mathrm{m}^{2}$. The capital cost of the required sustainable energy systems for covering all the annual energy requirements in the hotel including a solar thermal system with flat plate collectors, a solar photovoltaic system with crystalline-Si modulus and high efficiency heat pumps has been estimated at $95.7 € / \mathrm{m}^{2}$ while the annual $\mathrm{CO}_{2}$ savings due to the use of benign energy systems in the hotel have been calculated at $68 \mathrm{kgCO}_{2} / \mathrm{m}^{2}$. It is concluded that the use of solar energy technologies in summeroperating hotels in the Mediterranean region could cover all their energy requirements, while it is technically feasible, economically profitable and environmentally desirable.
\end{abstract}

Keywords: carbon neutral, Crete, Greece, electricity, heat, hotel, Mediterranean, renewable energy, solar energy

\section{Introduction}

The global threat of climate change has increased the efforts of the international community to decrease the use of fossil fuels in order to mitigate the greenhouse effect. Energy consumption in hotel buildings is high compared with other building categories. Hotels utilize mainly electricity and fossil fuels for covering their energy needs while the use of renewable energies is rather limited. However current advances in various renewable energy technologies have reduced their cost and increased their attractiveness for heat, cooling and power generation. In areas with high potential in renewable energy resources, their use in hotels consists of a challenge offering economic and environmental benefits. Solar energy in the Mediterranean region is abundant while solar energy technologies can generate heat, cooling and electricity in a cost-effective way. Investigation of using solar energy technologies in hotels for covering their energy requirements could indicate the way for reducing their carbon footprint and improving their sustainability.

Santamouris et al, 1996 have reported on energy conservation and retrofitting potential in Hellenic hotels. The authors analyzed 158 hotels, calculating their annual average energy consumption at $273 \mathrm{KWh} / \mathrm{m}^{2}$. They also stated that the hotels can easily achieve a $20 \%$ overall energy conservation. Moia-Pol et al, 2005 reported on energy consumption in hotels in Mediterranean islands. The authors stated that energy audits in hotels in the Balearic Islands, Spain indicated that the share of electricity was 54\%, of LPG $10 \%$ and of diesel oil $36 \%$. They also mentioned that integration of renewable energies in hotels, particularly solar energy, is an excellent challenge for the hotel sector. Moia-Pol et al, 2014 reported on renewable energy applications in Mediterranean hotels. The authors stated that summer-operating hotels in the Balearic Islands consume on average $150 \mathrm{KWh} / \mathrm{m}^{2}$ while more than $50 \%$ of their total energy demand comes from thermal applications including heating, ventilation and airconditioning (HVAC) and domestic hot water (DHW). They concluded that the use of renewable energies or trigeneration plants could reduce fossil fuels use by $20-40 \%$. Vourdoubas, 2016 reported on energy consumption and the use of renewable energies in hotels in Crete, Greece. The author mentions that the energy analysis of five 
summer-operating hotels in Crete, Greece indicated that on average their annual energy consumption was 149 $\mathrm{KWh} / \mathrm{m}^{2}$ while electricity was the main energy source used with a share of $65-85 \%$ in their total energy use. Parpairi, 2017 investigated the energy use in small-scale Greek hotels. The author presented a list of available strategies in order to promote energy sustainability in Greek hotels. She emphasized the need for increased use of renewable energy technologies in them. Rezachek et al, 2001 reported on energy efficiency and renewable energy use in the hotel industry with reference to Sweden and Hawaii. Analyzing two middle-size hotels in these two countries, the authors estimated the specific energy consumption in Hawaii at $258 \mathrm{KWh} / \mathrm{m}^{2}$ and in Sweden at 360 $\mathrm{KWh} / \mathrm{m}^{2}$. They also stated that solar energy (thermal and photovoltaic) could provide more than $61 \%$ of a hotel's total energy requirements in Hawaii. Lengefend, 2016 reported on renewable energy use in the hotel sector on islands. The author reported some good examples of renewable energy applications worldwide including solar thermal, solar photovoltaic (solar-PV), wind power, biomass, geothermal energy and sea water cooling. He concluded that there are various obstacles hindering the use of renewable energy technologies in the hotel sector focused mainly on financial aspects. Vourdoubas, 2018 reported on the feasibility of creating net zero carbon emissions hotels in the Mediterranean region. The author stated that the creation of these hotels is technically feasible, economically profitable and environmentally desirable. He also stated that this can be obtained with the use of solar energy technologies combined with high efficiency heat pumps and solid biomass if needed. Kresteniti, 2017 studied the energy optimization of existing Greek hotel buildings using computer simulation. The author estimated that an average reduction of annual primary energy consumption at $60 \%$ can be achieved using energysaving techniques and renewable energy technologies. The average cost for that has been calculated at $93 € / \mathrm{m}^{2}$ while the payback period of the investments was 19 years. Bischoff et al, 2016 studied the use of renewable energy technologies in a new hotel in Amsterdam using computer simulation. The authors mentioned that by using solar$\mathrm{PVs}$, the renewable energy fraction in the total energy mix could reach $75 \%$. They also investigated the use of micro-turbines and co-generation systems, suggesting that due to the large surface required for the installation of solar-PVs, renting a space near the hotel should be examined. Tang et al, 2016 reported on energy performance of hotel buildings in China. Surveying 24 hotels, the authors calculated their annual energy intensity between 180.8 $\mathrm{KWh} / \mathrm{m}^{2}$ and $70.2 \mathrm{KWh} / \mathrm{m}^{2}$. The higher intensity corresponded to four-star hotels while the lower referred to onestar hotels. They also stated that electricity was the dominant energy source used, accounting for $81 \%$ of total energy consumption while solar energy was the main energy source used for DHW production. Dhirasasna et al, 2017 investigated various parameters influencing the deployment of renewable energy technologies (RETs) in the hotel sector in Queensland, Australia. Analyzing the data collected by stakeholders, the authors stated that "the reliability of electricity generated by RETs" and "comfort of tourists" were important parameters in the decisionmaking while "the existence of a green program in the hotel" and "the energy storage" were less important parameters. Reckoska et al, 2008 reported on energy consumption in a hotel industry in Ochrid, Former Yugoslavian Republic of Macedonia. The authors analyzed the fourteen most important hotels in Ochrid, stating that the main energy sources used were electricity, gas and oil, while one third of them were using solar collectors for hot water production. Buonomono et al, 2015 assessed the performance of a hybrid geothermal-solar trigeneration system in a hotel in Ischia, Italy. The authors modeled a system using geothermal fluid at $95^{\circ} \mathrm{C}$, solar energy collectors with an area of $25 \mathrm{~m}^{2}$ and an Organic Rankine cycle micro-turbine at $6 \mathrm{KW}_{\mathrm{el}}$. Using simulation techniques, they estimated its payback time at 7.6 years which could be decreased if subsidies were offered for hotels. An analysis on energy use by European hotels [Hotel energy solutions, 2011] investigated five options of renewable energy technologies including biomass, geothermal energy, solar thermal, solar cooling and solar-PV. It concludes that the most interesting technology for hotel uses is solar thermal followed by solar-PV. A report on solar thermal heating [Grantham Institute, 2017] stated that solar thermal technology is a mature technology capable of mass deployment in Europe while there are opportunities in many European countries for the installation of more solar thermal systems. It also states that solar thermal collectors can be combined with solar-PV modulus to produce, simultaneously, heat and electricity. A solar cooling position paper by the International Energy Agency, 2015 provides arguments on why and how solar cooling systems should be supported and promoted. The report states that more than 1200 solar thermal cooling systems have been installed in recent years. It also mentions that market opportunities exist in places with high solar irradiance and high coincidence of loads and solar gains while it is indicated that hotel buildings are good candidates for such applications. According to a report by the International Institute of Refrigeration, 2017, single-effect solar thermal cooling systems obtain coefficients of performance (COP) between 0.4 when the temperature of the hot fluid is around $70^{\circ} \mathrm{C}$, and 0.8 when the temperature is around $85-90^{\circ} \mathrm{C}$. Cuce et al, 2018 reported on theory and applications of hybrid solar photovoltaic/thermal (PV/T) systems. The authors stated that these systems can achieve electric efficiencies in the range of $8-14 \%$ while concentrated systems can reach up to $30 \%$. Thermal efficiency is a function of ambient parameters and it can vary significantly. However thermal efficiencies in the range of $30-40 \%$ are realistic, 
although different values have been observed in pilot tests and in real applications. They also mentioned that payback periods of hybrid solar PV/T systems can vary between 4-14 years. Tselepis et al, 2002 have analyzed hybrid solar PV/T systems regarding their energy generation and economic performance. The authors calculated the energy generation in Athens, Greece $\left(38^{\circ}\right)$ with hybrid solar PV/T systems with amorphous and polycrystalline-Si cells. Solar irradiance in Athens is $1686.87 \mathrm{KWh} / \mathrm{m}^{2}$ at $40^{\circ}$ inclination of the panels. For the solar $\mathrm{PV} / \mathrm{T}$ system with amorphous-Si, the annual electric efficiency was $5.27 \%$ and the heat efficiency $40.41 \%$. For the solar PV/T system with poly-crystalline-Si, the annual electric efficiency was $12.61 \%$ and the thermal efficiency $35.83 \%$. They also estimated the payback period for the hybrid solar PV/T systems, concluding that systems with amorphous-Si were more attractive with payback periods around 5 years while systems with poly-crystalline-Si had higher payback periods at 8-10 years. Hotel Stadthalle located in Vienna is a medium-size city hotel with zeroenergy balance which generates, annually, with renewable energies, the same amount of energy that it consumes. The hotel uses renewable energy technologies to achieve that, including solar thermal and solar-PV panels, groundwater heat pumps and three small wind turbines.

The aims of the current work are:

a) The investigation of the possibility of using solar energy technologies combined with heat pumps for covering all the energy needs in summer-operating hotels with reference to the island of Crete, Greece, and

b) The economic and environmental assessment of the use of these technologies in hotels.

\section{Energy Consumption in Hotels in the Mediterranean Region}

Hotels consume energy in various sectors including space heating and cooling, domestic hot water production, lighting and operation of various equipment and devices. The distribution of energy consumption per sector varies depending on various parameters including local climate, type of construction, size of the hotel, period of operation and behavior of tourists. Published data indicate that hotel buildings are among the highest energy-consuming buildings. It is also indicated that the main energy source used is electricity while the share of renewable energies in their energy mix is rather low. Published data have reported that hotels in Greece consume on average annually $273 \mathrm{KWh} / \mathrm{m}^{2}$ while summer-operating hotels in the Mediterranean islands have an annual energy consumption of around $150 \mathrm{KWh} / \mathrm{m}^{2}$. In these hotels located in the Mediterranean basin, a large share of energy is consumed in HVAC and in DHW production, which together have a share higher than $50 \%$ of the total energy use.

\section{Use of Solar Energy Technologies in Hotels}

Summer-operating hotels in the Mediterranean region require energy when solar irradiance is high. Therefore it would be easier to use solar energy technologies in those hotels for covering all their energy needs. They require simultaneously electricity, cooling energy and DHW. Nowadays most of them use grid electricity for lighting, airconditioning and the operation of various electric devices. They also use diesel oil or solar thermal energy for DHW production. Most of their energy requirements are covered with these energy sources and fuels. The high availability of solar energy in the Mediterranean region creates a challenge for its use in the hotel sector. At the same time, current advances in solar energy technologies have increased their competitiveness as alternative technologies while their use is more than desirable for many reasons. Unfortunately only solar thermal energy is currently used in some hotels for DHW production and recently solar-PV systems for electricity generation, due to the sharp decrease in their cost. Solar thermal cooling is a promising technology but it has limited applications. There are various commercial installations worldwide but this technology has not been propagated so far. Hybrid solar PV/T technology can produce, simultaneously, electricity and thermal energy from the same system with a high overall efficiency. It is a promising technology but it needs further development and demonstration in order to be commercialized. In fact, solar energy, combined with high efficiency heat pumps, could be used for covering the energy demand in all sectors in summer-operating hotels.

Table 1. Possibility of using solar energy technologies in various sectors in summer-operating hotels in the Mediterranean region

\begin{tabular}{lll}
\hline Energy needs & $\begin{array}{l}\text { Main energy sources/fuels } \\
\text { currently used }\end{array}$ & $\begin{array}{l}\text { Solar energy technologies which } \\
\text { could be used }\end{array}$ \\
\hline Space cooling & $\begin{array}{l}\text { Grid electricity powering the air- } \\
\text { conditioning system }\end{array}$ & $\begin{array}{l}\text { Solar thermal cooling } \\
\text { Solar-PV powered heat pumps }\end{array}$ \\
DHW production & Diesel oil, gas and solar thermal & Solar thermal \\
\hline
\end{tabular}


Lighting and operation of various electric devices including airconditioning

Grid electricity

Solar-PV

The efficiencies of the solar energy systems which could provide all the energy required in a summer-operating hotel in the Mediterranean region are presented in Table 2. The efficiency of commercial solar-PV systems with flat plate crystalline-Si modulus is around 15\% while simple solar thermo-siphonic systems for DHW production in the Mediterranean region with flat plate collectors have efficiencies of around $50 \%$. Solar thermal cooling with single-stage systems and hot water temperature at $70 \mathrm{oC}$ has a low efficiency of around $40 \%$. It should be noted that these efficiencies are indicative and they can vary depending on the systems used and the local climate conditions. Parabolic or concentrated collectors and panels have higher efficiencies than flat plate collectors while the efficiency of solar thermal cooling can be increased significantly if a multi-stage system is used or if the temperature of the hot fluid is higher than $70^{\circ} \mathrm{C}$.

Table 2. Typical energy efficiency in various commercial solar energy systems and low carbon emissions systems in the Mediterranean region

\begin{tabular}{lcc}
\hline Technology & $\begin{array}{c}\text { Energy efficiency- } \\
\text { electric }\end{array}$ & $\begin{array}{l}\text { Energy efficiency - } \\
\text { heat/cooling }\end{array}$ \\
\hline Solar-PV & $15 \%$ & \\
$\begin{array}{l}\text { Solar thermal for DHW } \\
\text { production at } 60-70^{\circ} \mathrm{C},\end{array}$ & $50 \%$ \\
thermo-siphonic & \\
systems with flat plate & \\
collectors & $40 \%$ \\
$\begin{array}{l}\text { Solar thermal cooling, } \\
\text { single-stage systems }\end{array}$ & \\
with hot water at $70^{\circ} \mathrm{C}$ & $350 \%$ \\
$\begin{array}{l}\text { High efficiency heat } \\
\text { pumps }\end{array}$ & \\
\hline
\end{tabular}

Note. Average values in published literature.

\section{Creation of Net Zero Carbon Emission Hotels}

In order to zero the net carbon emissions due to operational energy use in a hotel, the following criteria should be fulfilled:

1. All the fossil fuels used for heat generation should be replaced with renewable energy sources, preferably locally available, and

2. All the grid electricity used in the hotel should be annually offset with green electricity, preferably with solarPV electricity.

The use of solar-PVs connected into the grid is allowed in buildings and enterprises according to the net-metering initiative which is in force for the last four years in Greece (Greek Ministerial Decree, 2014). Although currently there are limitations regarding the maximum power allowed for solar-PV systems installed with net metering regulations in the Greek islands, it is expected that they will be removed after the interconnection of the electric grids of Crete and continental Greece. It should be noted that the share of fossil fuels in grid electricity generation in Crete is approximately $80 \%$ while the remaining $20 \%$ is derived from renewable energies, mainly solar-PV and wind energy. Therefore offsetting all the grid electricity used in a hotel annually with green solar electricity will result in negative carbon emissions in it.

\section{Sizing of the Energy Systems Required}

In order to calculate the size of the solar energy systems required in a summer-operating hotel, the following assumptions have been made: 
a) The covered surface of a summer-operating hotel in Crete, Greece is $3000 \mathrm{~m}^{2}$ and its specific annual energy consumption is $150 \mathrm{KWh} / \mathrm{m}^{2}$,

b) The share of electricity in the total energy mix is $40 \%$, in DHW production $25 \%$ and in space cooling $35 \%$,

c) Energy efficiencies in the energy systems used are similar with those in Table 2,

d) The hotel will generate and offset with solar-PV modulus the same amount of grid electricity consumed annually according to the net-metering regulations,

e) A high efficiency heat pump could be used for space cooling having a COP at 3.5. Its power will be double the power required to cover the average cooling loads in the hotel, and

f) DHW will be produced with solar thermo-siphonic systems having flat plate collectors.

Energy consumption in the summer-operating hotel in Crete, Greece is presented in Table 3

Table 3. Energy consumption in a typical summer-operating hotel in Crete, Greece

\begin{tabular}{lc}
\hline Covered area in the hotel & $3000 \mathrm{~m}^{2}$ \\
\hline Annual specific energy consumption & $150 \mathrm{KWh} / \mathrm{m}^{2}$ \\
\hline Annual total energy requirements & $180000 \mathrm{KWh}$ \\
\hline Annual electricity requirements $(40 \%$ of the total) & $112500 \mathrm{KWh}_{\mathrm{th}}$ \\
$\begin{array}{l}\text { Annual energy consumption for DHW production } \\
\text { (25\% of the total) }\end{array}$ \\
$\begin{array}{l}\text { Annual energy requirements for space cooling }(35 \% \\
\text { of the total) }\end{array}$ \\
$\begin{array}{l}\text { Annual electricity requirements for a heat pump with } \\
\text { COP } 3.5 \text { powering the air conditioning system } \\
\text { generating } 157500 \mathrm{KWh} \text { cool }\end{array}$ \\
$\begin{array}{l}\text { Total annual electricity requirements including the } \\
\text { operation of the heat pump }\end{array}$
\end{tabular}

Sizing of the solar energy systems and the heat pump required are presented in Table 4.

Table 4. Sizing of the energy systems required in the hotel

\begin{tabular}{lccc}
\hline Energy system & Energy generation & Energy efficiency & Size \\
\hline Solar-PV & $225000 \mathrm{KWh}_{\mathrm{el}}$ & $15 \%$ & $\begin{array}{c}\text { Nominal power } 150 \\
\mathrm{KW}_{\mathrm{p}}\end{array}$ \\
$\begin{array}{l}\text { Solar thermal } \\
\text { High efficiency heat }\end{array}$ & $112500 \mathrm{KWh}_{\text {th }}$ & $50 \%$ & $\begin{array}{c}\text { Area of the flat plate } \\
\text { collectors } 125 \mathrm{~m}^{2}\end{array}$ \\
pumps & $1500 \mathrm{KWh}_{\text {cool }}$ & $350 \%$ & Electric power $42 \mathrm{KW}_{\mathrm{el}}$ \\
\hline
\end{tabular}

\section{Capital Cost of the Energy Systems}

The following assumptions have been made for the estimation of the capital cost of the energy systems:

1. The capital cost of the solar-PV system is $1300 €$ per $\mathrm{KW}_{\mathrm{p}}$,

2. The capital cost of the solar thermo-siphonic system is $300 €$ per $\mathrm{m}^{2}$ of the collectors, and 
3. The capital cost of the Heat Pump is $1200 €$ per $\mathrm{KW}_{\mathrm{el}}$.

The capital cost of the energy systems required is presented in Table 5.

Table 5. Capital cost of the energy systems

\begin{tabular}{|c|c|c|}
\hline Energy system & Capital cost $(€)$ & Capital cost $\left(€ / \mathrm{m}^{2}\right)$ \\
\hline Solar-PV & 195000 & 65 \\
\hline Solar thermal & 37500 & 12.5 \\
\hline $\begin{array}{l}\text { High efficiency heat } \\
\text { pumps }\end{array}$ & 54600 & 18.2 \\
\hline Total & 287100 & 95.7 \\
\hline
\end{tabular}

\section{Environmental Considerations}

In order to estimate the environmental benefits concerning the reduction of $\mathrm{CO}_{2}$ emissions due to operational energy use in the abovementioned hotel using solar energy technologies, the hotel is compared with a similar hotel using only fossil fuels, as follows:

a) Grid electricity is covering all its electricity requirements including powering the heat pump,

b) A high efficiency heat pump with COP at 3.5 is used for space cooling, and

c) DHW is produced with the use of diesel oil.

Carbon emissions in the hotel are presented in Table 6.

Table 6. Carbon emissions in a summer-operating hotel using only fossil fuels

\begin{tabular}{lccc} 
Hotel sector & $\begin{array}{c}\text { Annual energy } \\
\text { consumption }\end{array}$ & $\begin{array}{c}\text { Annual } \mathrm{CO}_{2} \text { emissions } \\
\left.(\mathrm{tnCO})_{2}\right)\end{array}$ & $\begin{array}{c}\text { Annual } \mathrm{CO}_{2} \text { emissions } \\
\left(\mathrm{kgCO}_{2} / \mathrm{m}^{2}\right)\end{array}$ \\
\hline $\begin{array}{l}\text { Lighting and operation } \\
\text { of various electric } \\
\text { devices }\end{array}$ & $180000 \mathrm{KWh}$ el & 135 & 45 \\
$\begin{array}{l}\text { Space cooling - } \\
\text { Electricity consumption } \\
\text { by the heat pump }\end{array}$ & $45000 \mathrm{KWh}_{\mathrm{el}}$ & 33.75 & 11 \\
DHW production & $112500 \mathrm{KWh}_{\mathrm{th}}$ & 34.20 & 12 \\
Total & $337500 \mathrm{KWh}$ & 202.95 & 68
\end{tabular}

Note: $\mathrm{CO}_{2}$ emissions due to electricity use, $0.75 \mathrm{kgCO}_{2}$ per $\mathrm{KWh}_{\mathrm{el}} ; \mathrm{CO}_{2}$ emissions due to diesel oil use, 0.304 $\mathrm{kgCO}_{2}$ per $\mathrm{kg}$

Therefore, theuse of solar energy only in the summer-operating hotel results in annual savings of $202.95 \mathrm{tnCO}_{2}$. The capital cost of the sustainable energy systems required per $\mathrm{kg}$ of annual $\mathrm{CO}_{2}$ emission savings is $1.41 €$.

\section{Discussion}

A preliminary calculation of the size of the energy systems required has been made without considering any improvement in the energy efficiency of the hotel. Since the solar collectors and modulus require large surfaces for their installation, it is possible that the surfaces are not available in the hotel. In this case a nearby place could be rented for their installation if possible. Solar thermal technology for DHW production and high efficiency heat pumps are mature technologies used for many years in hotels. Solar-PV technology though has been used only in recent years since it is now considered profitable and the net-metering regulations allow it. In Greece, promotion of sustainable energy technologies in hotels is currently subsidized through EU structural funds. The estimated capital cost of the energy systems required for achieving carbon neutrality is not considered high compared with the construction cost of the hotels. The capital cost of the energy systems required according to the present study at $95.7 € / \mathrm{m}^{2}$ is comparable, with similar cost reported by Kresteniti, 2017 at $93 € / \mathrm{m}^{2}$, although in the second study 
sustainable energies did not supply all the energy required in the hotel. Future improvements of solar thermal cooling and solar hybrid PV/T technologies could allow the use of additional solar energy technologies in the hotel sector. Successful operation for many years of a middle-size hotel in Vienna achieving net zero energy balance and net zero carbon emissions proves the operational and economic feasibility of the use of sustainable energy technologies in the hotel sector. Since the proposed sustainable energy technologies are mature, reliable and costeffective, it is indicated that the cost is not a parameter hindering their promotion in the hotel sector. Increased use of solar energy instead of fossil fuels in hotels in Mediterranean countries could reduce their dependence on imported fossil fuels and would also reduce their impact on climate change.

\section{Conclusions}

Solar energy can be used in summer-operating hotels in the Mediterranean region for covering part or all of their operational energy requirements. Solar thermal technology for DHW production and solar-PV technology for electricity generation are reliable and cost-effective technologies which are currently used in various applications. Additionally, high efficiency heat pumps are used for space cooling in hotels. Solar-PV systems can be used with net-metering regulations for covering part or all of the electricity requirements in them. Other solar energy technologies like solar thermal cooling and hybrid solar PV/T systems require further improvements in order to be used broadly on a commercial scale. Annual energy consumption in summer-operating hotels in the Mediterranean region is around $150 \mathrm{KWh} / \mathrm{m}^{2}$. The capital cost of the sustainable energy systems required to cover all the annual energy needs in these hotels has been calculated at $95.7 € / \mathrm{m}^{2}$, while the annual $\mathrm{CO}_{2}$ savings due to use of these energy systems have been calculated at $68 \mathrm{kgCO} / \mathrm{m}^{2}$. It is concluded that use of solar energy technologies in hotels in the Mediterranean region is technically feasible, cost-effective and environmentally friendly. Further research should be focused on the creation of a net zero energy hotel in Crete, Greece using solar energy technologies. The operation of the energy systems should be monitored in order to verify their performance.

\section{References}

Bischoff, J., Hensen, J. L. M., Handy, H. M., \& Philips, C. (2016). Renewable energy technology feasibility study for a new hotel building in Amsterdam. European Heating, Ventilation, Air-conditioning (REHVA) Journal, 21-27.

Buonomano, A., Calise, F., Palombo, A., \& Vicidomini, M. (2015). Energy and economic analysis of geothermalsolar tri-generation systems: A case study for a hotel building in Ischia. Applied Energy, 138, 224-241. https://doi.org/10.1016/j.apenergy.2014.10.076

Cuce, E., Oztekin, E. K., \& Cuce, P. M. (2018). Hybrid photovoltaic thermal systems: From theory to applications. Energy Research Journal, 9(1), 1-71. https://doi.org/10.3844/erjsp.2018.1-71

Dhirasasna, N, Sahim, O., \& Becken, S. (2017). The effect of renewable energy technology uptake by the hotel sector. $22^{\text {nd }}$ International Congress on Modelling and Simulation, Hobart, Tasmania, Australia, 3-8/12/2017, (pp. 1413-1419).

Hotel Energy Solutions (2011). Analysis on Energy Use by European Hotels: Online Survey and Desk Research. Retrieved January 14, 2019, from https://hes.unwto.org/sites/all/files/docpdf/analysisonenergyusebyeuropeanhotelsonlinesurveyanddeskresear ch2382011-1.pdf

Kresteniti, A. (2017). Development of a concept for energy optimization of existing Greek hotel buildings. Procedia Environmental Sciences, 38, 290-297. https://doi.org/10.1016/j.proenv.2017.03.080

Lengfeld, K. (2016). Renewable energy and energy efficiency in the hotel sector on islands. Good practices, obstacles and lessons learnt. IHK Stuttgart, 16/3/2016. Retrieved January 14, 2019, from https://www.german-energy-

solutions.de/GES/Redaktion/DE/Audioslidehows/2016/Kapverden/Vortrag4/praesentation.pdf?_blob=publ icationFile \& $v=1$

Ministerial Decree, Greek Ministry of Environment, Energy and Climatic Change (YPEKA), 30/12/2014,

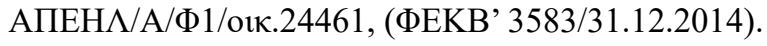

Moia-Pol, A., Karagiorgas, M., Coll-Mayor, D., Martinez-Moll, V., \& Riba-Romeva, C. (2005). Evaluation of the energy consumption in Mediterranean islands hotels: Case study: The Balearic islands hotels. Renewable Energy and Power Quality Journal, 1(3), 105-109. https://doi.org/10.24084/repqj03.233

Moia-Pol, A., Karagiorgas, M., Martinez-Moll, V., Pujol, R., \& Riba-Romeva, C. (2014). Evaluation of the renewable energy application in Mediterranean hotels: Case Study: The Balearic islands hotels. Retrieved 
May 10, 2018, from https://www.researchgate.net/publication/239582784

Parpairi, K. (2017). Sustainability and energy use in small scale Greek hotels: Energy saving strategies and $\begin{array}{lllll}\text { Environmental policies. Procedia Environmental } & \text { Sciences, } & \text { 38, }\end{array}$ https://doi.org/10.1016/j.proenv.2017.03.099

Quality assurance and support measures for solar cooling, task 48, International Energy Agency, 2015. Retrieved December 13, 2018, from http://www.iea-shc.org/data/sites/1/publications/IEA-SHC_Solar-CoolingPosition-Paper_Sep2015.pdf

Reckoska, G. P., Reckoski, R., \& Vasileska, A. (2008). Energy consumption in hotel industry-Case study in Ohrid. Tourism and Hospitality Management, 14(2), 291-300.

Rezachek, D., Martinac, I., \& Bohdanowicz, P. (2001). Energy efficiency and renewable energy use in the hotel industry-Two case studies (Hawaii and Sweden). ISES, Solar World Congress, November 2001, Sydney, Australia.

Santamouris, M., Balaras, C. A., Dascalaki, E., Argiriou, A., \& Gaglia, A. (1996). Energy conservation and retrofitting potential in Hellenic hotels. Energy and Buildings, 24, 65-75.

Solar Cooling (2018). 34 $4^{\text {th }}$ Informatory note on refrigeration technologies, International Institute of Refrigeration, April 2017. Retrieved December 17, 2018, from http://www.iifiir.org/userfiles/file/publications/notes/NoteTech_34_EN.pdf

Solar-thermal and hybrid Photovoltaic-thermal systems for renewable heating. (2017). Granthman Institute, Imperial College London, Briefing paper 22. Retrieved December 17, 2018, from https://www.imperial.ac.uk/media/imperial-college/grantham-institute/public/publications/briefingpapers/2679_Briefing-P-22-Solar-heat_web.pdf

Tang, M., Fu, X., Cao, H., Shen, Y., Deng, H., \& Wu, G. (2016). Energy performance of hotel buildings in Lijiang, China. Sustainability, 8, 780. https://doi.org/10.3390/su8080780

Tselepis, S., \& Tripanagnostopoulos, Y. (2002). Economic analysis of hybrid photovoltaic/thermal solar systems and comparison with standard PV modules. Proceedings of International Conference on PV in Europe, 7-11 October 2002, Rome, Italy, (pp. 856-859).

Vourdoubas, J. (2016). Energy consumption and use of renewable energy sources in hotels: A case study in Crete, Greece. Journal of Tourism Hospitality and Management, 4(2), 75-87. https://doi.org/10.15640/jthm.v4n2a5

Vourdoubas, J. (2018). Hotels with net zero carbon emissions in the Mediterranean region: Are they feasible? Journal of Tourism and Hospitality Management, 6(2), 72-79. https://doi.org/10.15640/jthm.v6n2a6

\section{Copyrights}

Copyright for this article is retained by the author(s), with first publication rights granted to the journal.

This is an open-access article distributed under the terms and conditions of the Creative Commons Attribution license (http://creativecommons.org/licenses/by/4.0/). 